\title{
Does Psychic Distance Still Matter? Empirical Evidence from Poland ${ }^{1}$
}

\author{
Krzysztof Fonfara², Aleksandra Hauke-Lopes ${ }^{3}$, Marcin Soniewicki ${ }^{4}$
}

Submitted: 8.04.2021. Accepted: 29.06.2021

\section{Abstract}

Objective: The objective of the article is to fill a research gap regarding the impact of psychic distance on the initiation of relationships by managers from Poland-based firms and to analyze the psychic distance's influence on firm performance.

Research methodology: The article is based on quantitative research conducted among managers from 201 Poland-based companies operating in foreign markets. The study used a structured questionnaire consisting mainly of closed questions. The dataset contained companies representing all sizes, industries, and ownership status from all over Poland.

Findings: Two types of companies were identified following managers' (un)willingness to initiate relationships with actors located in psychically distant markets. The study conclusions reveal that psychic distance matters for Polish managers and that business activities conducted in psychically distant markets are often perceived as more complex than in close markets. These activities involve additional risk, but they bring companies better performance.

Limitations: The limitation of the study is that the measurements are based on the subjective perceptions of psychic distance. The research was conducted in Poland only.

Originality: The article is a pioneer work on the psychic distance paradox among Polish managers from a diversified group of companies (from small to multinational). The article seeks to identify to what extent Polish managers perceive psychic distance as an important factor in the decision-making process concerning the initiation of relationships with foreign partners.

Keywords: psychic distance, business relationships, internationalization, company performance, Poland, CEE-EU.

JEL: F23, L21, L25

\footnotetext{
1 The article was written thanks to financial support from Poland's National Science Centre, Decision no. DEC-2013/09/B/HS4/01145, project title: The maturity of a company's internationalization and its competitive advantage (network approach).

2 Poznan University of Economics and Business - Department of International Marketing, Al. Niepodległości 10, 61-875 Poznan, Poland; e-mail: krzysztof.fonfara@ue.poznan.pl; https://orcid.org/0000-0003-0327-486X.

3 Poznan University of Economics and Business - Department of International Marketing, Al. Niepodległości 10, 61-875 Poznan, Poland; e-mail: aleksandra.hauke-lopes@ue.poznan.pl; https://orcid.org/0000-0002-0879-5499.

4 Poznan University of Economics and Business - Department of International Marketing, Al. Niepodległości 10, 61-875 Poznan, Poland; e-mail: marcin.soniewicki@ue.poznan.pl; https://orcid.org/0000-0001-6594-7180.
} 


\section{Introduction}

While the debate on psychic distance continues, there is no commonly accepted view of how to understand this concept (Ciszewska-Mlinarič and Trąpczyński, 2016). Most researchers show culture to be a key component of psychic distance. According to Evans, "the distance between the home market and a foreign market resulting from the perception and understanding of cultural and business differences" (Evans, 2000, p. 377-378). Some authors go even further and use psychic and cultural distance as synonymous concepts (e.g. Luo, Shenkar, and Nyaw, 2001; Drogendijk and Slangen, 2006). This perspective is followed by a growing number of studies, which adopt and investigate the individual perception of psychic distance (Sousa and Bradley, 2006; Dinner, Kushwaha, and Steenkamp, 2019; Ciszewska-Mlinarič, Obłój, and Hülsdau, 2019; Puthusserry et al., 2021). We adhere to this view and consider psychic distance (cultural distance) in the context of how it is perceived by the individual, which can influence managers' decisions about a company's internationalization process.

In the article, we analyze the importance of psychic distance for initiating the internationalization process. In this respect, we adopt the relationship view, according to which the internationalization process means initiating and developing relationships with actors from different cultural and business backgrounds. As stressed by Johanson and Vahlne, "now the business environment is viewed as a web of relationships, a network, rather than a neoclassical market with many independent suppliers and customers" (Johanson and Vahlne, 2009, p. 1411). Continuous changes in the global economy require firms to cooperate as only the development of relationships enables companies to exist.

The concept of psychic distance assumes that individual perceptions of psychic distance may affect managers' choices regarding markets for expansion. Psychic distance has been - and still is - considered an important factor that impacts decisions concerning the selection of potential foreign markets for internationalization (Safari and Chetty, 2019; Moalla and Mayrhofer, 2020; Liu et al., 2021). As a result of globalization, improvements in communication, and the development of new technologies, the concept of psychic distance is evolving. Therefore, some researchers posit that we must change how we perceive and measure psychic distance (Hutzschenreute et al., 2014; Tung and Stahl, 2018) by underlining its decreasing influence on managers' internationalization decisions (Zaheer et al., 2012). Since the debate continues regarding the importance and influence of psychic distance on the initiation of a company's internationalization process, we contribute to this discussion by investigating the current impact of psychic distance on managers' internationalization decisions using the example of Poland-based companies. 
In the existing literature, there is also a lack of agreement to what extent (if at all) psychic distance impacts a company's performance (Dikova, 2009; Dinner, Kushwaha, and Steenkamp, 2019). Researchers draw different conclusions in this area, therefore the objective of our article is to fill a research gap regarding the impact of psychic distance on the initiation of relationships by managers from Poland-based firms and to analyze its influence on firm performance. In our study, based on earlier research experiences (Fahy et al., 2003; Fonfara, Małys, and Ratajczak-Mrozek, 2018), we have decided to measure a company's performance on a relative basis. To this end, we used the consolidated performance indicator applied e.g. by Fonfara (2009), which is an arithmetic average of the four measurements of performance: profit, sales, market share, and return on investment (ROI).

In this article, we want to focus on companies located in Poland. After years of isolation during the communist period, Poland and other EU countries from Central and Eastern Europe (CEE-EU) made significant progress in terms of economic development, including internationalization. This has become particularly visible after the 2004 accession to the European Union. There are many studies on psychic distance that focus on EU markets from non-Central and Eastern Europe (non-CEE-EU), and the literature on the matter is widely available. As for the CEE-EU countries, the research is relatively less extensive, and psychic distance is investigated in the context of foreign investments in CEE-EU countries (Dikova, 2009; Dow and Ferencikova, 2010), transborder cooperation (Leick, 2011), or through a specific perspective such as the selection of markets for internationalization by CEE-EU enterprises (Babichenko, 2006). Only a few studies analyze Polish managers' perceptions of psychic distance during internationalization processes by focusing on the choice of a foreign market or selected modes of internationalization (e.g. Wach, 2015; Hauke-Lopes, 2018; Olejnik-Nizielska, 2018; Ciszewska-Mlinarič, Obłój, and Hülsdau, 2019). Our research proposes a novel perspective on the analysis of psychic distance as - to the best of our knowledge - there are no studies that investigate the impact of psychic distance on company performance as perceived by Polish managers. Polish companies are undergoing a generational change, which results in the co-functioning of managers from different generations, with different international experience and language skills. Therefore, the analysis of managers' attitudes toward entering new, psychically distant markets and the impact of these decisions on company performance may shed new light on the issue of psychic distance. Therefore, this article seeks to fill this gap on the example of managers from Poland-based firms to investigate the impact of psychic distance on the initiation of business relationships with foreign partners, along with company performance.

In our study for this article, we did not want to concentrate on any specific internationalization forms. Instead, we focused on the issue of initiating relationships with 
foreign partners, which naturally is a comprehensive matter that embraces all modes of foreign market entry used by the companies studied. Additionally, our intention was not to treat companies located in Poland as a specific case within the European Union (or Europe). Rather, because of the abovementioned underresearched context of CEE-EU countries, we wondered how the results of our study would relate to research presented earlier, specifically to different views on the role of psychic distance in managers' decisions on internationalization. Furthermore, we would like to examine another relatively unexplored issue related to psychic distance, namely its impact on a company's performance.

In the first part of this article, a literature review on the concept and significance of psychic distance will be conducted, along with an analysis of the impact of psychic distance on relationship initiation. We will present a critical review of the problem based on non-CEE-EU and CEE-EU countries, including Poland. The analysis will be followed by a literature review on the impact of psychic distance on company performance as perceived by managers (from non-CEE-EU countries and CEE-EU countries). In the second part of the article, the results of the empirical study will be presented and discussed. The quantitative study was conducted among a diverse group of Polandbased companies; this article is based on answers from 204 respondents. In the last part of the article, the conclusions and managerial implications will be presented.

\section{Psychic Distance: Concept and Significance}

The concept of psychic distance assumes that the process of internationalization involves differences (e.g. cultural, economic, legal) that affect the exchange of information, which influences managers' decisions and how they perceive foreign markets (Johanson and Wiedersheim-Paul, 1975; Nebus and Chai, 2014; Liu et al., 2021). In this article, we follow existing studies in understanding the internationalization process as one of initiating and developing relationships with actors in a foreign market (Deszczyński, Fonfara, and Dymitrowski, 2017; Vahlne and Johanson, 2017). As the debate on psychic distance continues, researchers do not share a common position on how to understand this concept. For example, Håkanson and Ambos emphasize that psychic distance depends on many factors, not just cultural ones. Based on their own results, they claim that "Perceptions of psychic distance ... are also affected by personal factors, such as individuals' values, motivation, and prior experience" (Håkanson and Ambos, 2010, p. 19). However, other studies claim cultural differences to be one of the sources of psychic distance that impact the selection of foreign markets but not ones of crucial importance (Maseland, Dow, and Steel, 2018, p. 1157). Similarly, Olaja 
states that "recent literature on international business has highlighted several differences between the terms [psychic distance and cultural distance] and concludes that cultural distance is only one, albeit important, component of wider concept of psychic distance" (Olaja, 2015, p. 827). Some authors go even as far as to use psychic and cultural distance interchangeably, as synonyms (Brewer, 2007; Musso and Francioni, 2012; Nizielska, 2013). Therefore, following the above approaches, in this article we consider cultural differences to be the crucial and most important component of psychic distance, as it heavily impacts managers' opinions on the choice of foreign market entry. As a consequence of such an approach - following e.g. Nizielska (2013) or Brewer (2007) - we understand cultural distance to be synonymous with the concept of psychic distance.

As there is no common view on the concept of psychic distance, the approach toward its measurement also remains a matter of debate (Zaheer et al., 2012). For some, psychic distance should be assessed between countries as the distance that individuals or groups feel with regard to a specific country (Håkanson and Ambos, 2010), or it should be viewed as aggregated differences among countries (Zaheer et al., 2012). However, Sousa and Bradley state that psychic distance "exists in an individual's mind and depends on how he or she perceives the world" (Sousa and Bradley, 2006, p. 51). Therefore, they claim that distance should be analyzed among individuals. As a result of such an approach, psychic distance is asymmetrical: the distance perceived by one person is not identical to the distance perceived by another person from a different foreign market (Ellis, 2008; Håkanson and Ambos, 2010). We adopt the individual perception of psychic distance in line with the growing research in that field (Magnani et al., 2018; Dinner et al., 2019; Safari and Chetty, 2019). We define psychic distance after Evans, Treadgold, and Mavondo as "the distance between the home market and a foreign market resulting from the perception and understanding of cultural and business differences" (2000, p. 377-378). This approach allowed us to analyze psychic distance at the individual level, but also to acknowledge the impact of external elements such as culture and business environment on the perceived psychic distance.

Despite considerable research on the topic, the impact of psychic distance on the decision to enter a foreign market also shows no universal approach among scholars. As a result of globalization, improvements in communication facilities, and advances in modern technologies, many earlier assumptions and theories about psychic distance evolved (Ambos and Håkanson, 2014). As Johanson and Vahlne claim in their revised model, psychic distance retains its importance, but "the correlation between the order in which a company enters foreign markets and psychic distance has weakened" (Johanson and Vahlne, 2009, p. 1421). This is the effect of acquiring new knowledge 
on foreign markets, along with an improved level of self-confidence among individuals who decide on the internationalization process. This view is not commonly shared among scholars. On the one hand, some researchers claim that despite globalization, psychic distance remains significant (Dinner, Kushwaha, and Steenkamp, 2019), while others recognize the impact of psychic distance e.g. on decisions about the internationalization process (Dow and Ferencikova, 2010). On the other hand, some studies show the low impact of psychic distance on the process of internationalization and prompt call for a change in our understanding of psychic distance (Hutzschenreuter et al., 2014).

As the literature review reveals, existing research presents contrasting views on the impact of psychic distance: from insignificant (Musso and Francioni 2012; Ambos and Håkanson, 2014; Ambos, Leicht-Deobald, and Leinemann, 2019) to still influencing internationalization decisions (Vahlne and Johanson, 2017; Safari and Chetty, 2019; Puthusserry et al., 2021). Therefore, we would like to contribute to the field of research by analyzing the role of psychic distance in internationalization decisions - understood as the process of initiating business relationships in foreign markets. More specifically, our intention is to identify to what extent Polish managers perceive psychic distance (cultural distance) as an important factor in the decision-making process concerning the initiation of relationships with foreign partners.

As mentioned above, there is an important stream of research that analyzes the psychic distance impact in non-CEE-CE markets. The existing research investigates perceived psychic distance in terms of the incremental learning of Spanish managers during FDI investments (Pla-Barber, 2001), examines the impact of distance dimensions on the choice of cooperative alliances by French companies in global markets (Moalla and Mayrhofer, 2020), or focuses on such impact during the internationalization process of Spanish small and medium-sized enterprises (SMEs) (Paul and Criado, 2020). The impact of psychic distance during the initiation of relationships is also investigated through the perspective of knowledge transfer within the relationships and sales transactions of Swedish SMEs (Nordman and Tolstoy, 2014). Others explore this problem through the lens of the Uppsala internationalization model. For example, Kontinen and Ojala (2010) investigate the impact of psychic distance on foreign market entry and entry choice by Swedish family SMEs so as to underline the role of "bridging factors" toward psychically distant markets. In turn, based on their research on Swedish SMEs in the manufacturing industry, Safari and Chetty (2019) emphasize the role of bridge-makers (actors who possess specific knowledge) in overcoming psychic distance in the pre-entry and post-entry phases of internationalization. 
Research on Poland and other CEE-EU markets in terms of the impact of psychic distance on the initiation of relationships in foreign markets remains scarce. The exceptions focus on the role of psychic distance through the Uppsala model or on selected and more specific aspects of psychic distance in the internationalization process. In the former group, studies investigate the role of psychic distance during the internationalization of Poland-based companies through the lens of the Uppsala model (KłysikUryszek and Kuna-Marszałek, 2014) or the applicability of the Uppsala model for SMEs' internationalization among Polish, Czech, Slovakian, Austrian, and German companies (Tuzová et al., 2015). In the latter group, studies cover the importance of cultural distance for Polish, German, and British managers in their cross-border activities (Chapman et al., 2008), the importance of psychic distance perceived by Polish managers in the internationalization process on European markets (Olejnik-Nizielska, 2018), or when entering the Saudi Arabian market (Hauke-Lopes, 2018). Other research analyzes psychic distance through the stages of learning in a Polish multinational company during the process of internationalization (Ciszewska-Mlinarič, Wójcik, and Obłój, 2020).

The above issue of underresearched psychic distance motivated us to examine how Polish managers perceive the impact of psychic distance on their decisions concerning the initiation of foreign business relationships. We assume that Polish managers are no coherent group in terms of perceived distance towards psychically distant markets. On the one hand, the older generation of managers may not always be open to making decisions to enter new, psychically distant markets, as they may lack personal international experience, language skills, and the ability to use new technologies that allow communication with distant business partners. On the other hand, the constantly growing younger generation of managers is responsible for making decisions on internationalization. These managers usually speak foreign languages, frequently travel abroad, and use new media to make contact with foreign markets, which may lower their perceived psychic distance to distant markets. Moreover, considering the literature's disagreement regarding the actual role of psychic distance in the internationalization decision-making process, we wish to contribute to the discussion on this topic. To this end, we propose the following hypothesis:

H1: Psychic distance influences managers in Poland-based companies on decisions concerning the initiation of business relationships with foreign partners. 


\section{Psychic Distance’s Impact on Company Performance}

Researchers draw different conclusions on the impact of psychic distance on company performance. This impact is mainly analyzed through transaction cost analysis. In this stream of research, psychic distance influences company performance negatively because it may entail additional costs, raise uncertainty levels, or cause misunderstandings (Håkanson, 2014; Dow et al., 2020). As a consequence of the liability of foreignness, foreign companies have to bear more operational costs compared to local companies (Mithani, 2017). Moreover, other studies indicate the negative impact of high distances on company performance (Datta and Puia, 1995) or at least a varied impact (Dinner et al., 2019).

There also appeared a contrary argument within the transaction cost analysis stream as O'Grady and Lane (1996) revealed the psychic distance paradox. They found that company activity in psychically close markets did not lead to better business performance because managers tended to ignore small but sometimes significant differences between markets. In contrast, the fact of conducting business activity in psychically distant countries made managers more aware of the differences between their national market and foreign markets, causing them to pay more attention and become more involved in activity in this market. Therefore, a large psychic distance positively influences company performance, which implies that entering a psychically close market is not always beneficial for a company in terms of its performance. Furthermore, Evans and Mavondo (2002) claim that a large psychic distance has a positive influence on company performance and can be positive for multinational companies as it helps them to increase subsidiaries' capabilities (Verbeke and Yuan, 2016).

The impact of psychic distance on company performance is also investigated in organizational learning and innovation theory, mainly through the knowledge perspective. In this stream, distance is considered to be an asset that may positively impact company performance due to mutual learning and enhanced creativity (Nordman and Tolstoy, 2014). With the high perception of psychic distance, innovations are adopted in organizational strategy, structure, and procedures to handle the new environment and uncertainties (Azar and Drogendijk, 2014). Researchers argue that when a company already experienced investing in a foreign market or when a subsidiary is established with local actors, the impact of psychic distance on company performance is not significant (Dikova, 2009). Psychic distance may also cause difficulties for companies in the post-entry phase due to the lack of knowledge about local markets, thus developing relationships with local actors is recommended (Safari and Chetty, 2019). 
So far, research on the impact of psychic distance on company performance mostly focused on enterprises from non-CEE-CE European markets. In this stream of research, studies analyze links between perceived psychic distance, marketing mix, and export performance among Spanish SMEs (Navarro-García et al., 2016). Others examine export performance through innovation and cultural distance perceived by Swedish managers (Azar and Drogendijk, 2016). Yet other studies investigate European export SMEs from 30 countries to confirm the validity of the psychic distance paradox and state that psychic distance remains the predictor of strategic choices of markets for internationalization (Ciszewska-Mlinarič et al., 2019).

After the 1990s transition period, companies from Poland and other CEE-EU countries started expansion on foreign markets, thus introducing the matter of psychic distance as a subject of analysis in international business. Nevertheless, existing research on the issue remains scarce. Available analyses focus on the impact of psychic distance as perceived by export managers on company performance among Slovenian export companies (Bodlaj and Vida, 2018). Other studies investigate the impact of psychic distance on company performance in terms of foreign direct investment: the analysis concentrates on the impact of psychic distance on decisions regarding foreign direct investment and the performance of foreign firms investing in Slovakia (Dow and Ferencikova, 2010). Some investigate links between psychic distance and subsidiary performance of Western European companies in CEE countries like Poland, Czech Republic, Slovakia, or Hungary (Dikova, 2009). That study showed that positive links between psychic distance and subsidiary performance appeared only when Western managers lacked market-specific knowledge (Dikova, 2009). To the best of our knowledge, there is no research that analyzes the impact of psychic distance as perceived by Polish managers on company performance. We would like to fill this research gap and contribute to the developing stream of research on CEE-EU companies and markets. Therefore, we wish to investigate the impact of perceived psychic distance among Polish managers on company performance. Furthermore, we would like to join the discussion on the actual influence of psychic distance on company performance, taking into consideration the abovementioned inconsistencies and different outcomes of studies in this respect. Based on the experience of earlier research (Fahy et al., 2003; Fonfara et al., 2018), we decided to measure company performance by analyzing profits, sales, market share, and ROI compared to closest competitors. In this study, we used a consolidated performance indicator in the version created by Fonfara (2009): as an arithmetic average of these four measures of performance. In our article, we would like to contribute to the above discussion by proposing the following hypothesis: 
H2: Psychic distance as perceived by Polish managers impacts company performance.

\section{Method}

Our empirical study concentrated on companies based in Poland and operating in foreign markets. Poland has enjoyed rapid international development during the last 20 years, especially since accessing the EU in 2004. For instance, Poland's exports in 2001 reached \$35 bn and increased to over \$264 bn in 2019 (O’Neill, 2021). In Central European countries, exports increased very similarly from $\$ 155$ bn in 2001 to over $\$ 1100$ bn in 2019 (“Trade Map” 2021). The shift in companies' internationalization observed in Poland reflects the changes that happen in this region.

The objective of our study was to fill a research gap on the impact of psychic distance on the initiation of relationships by managers from Poland-based firms, and to analyze its influence on company performance (see Figure 1).

Figure 1. The conceptual framework

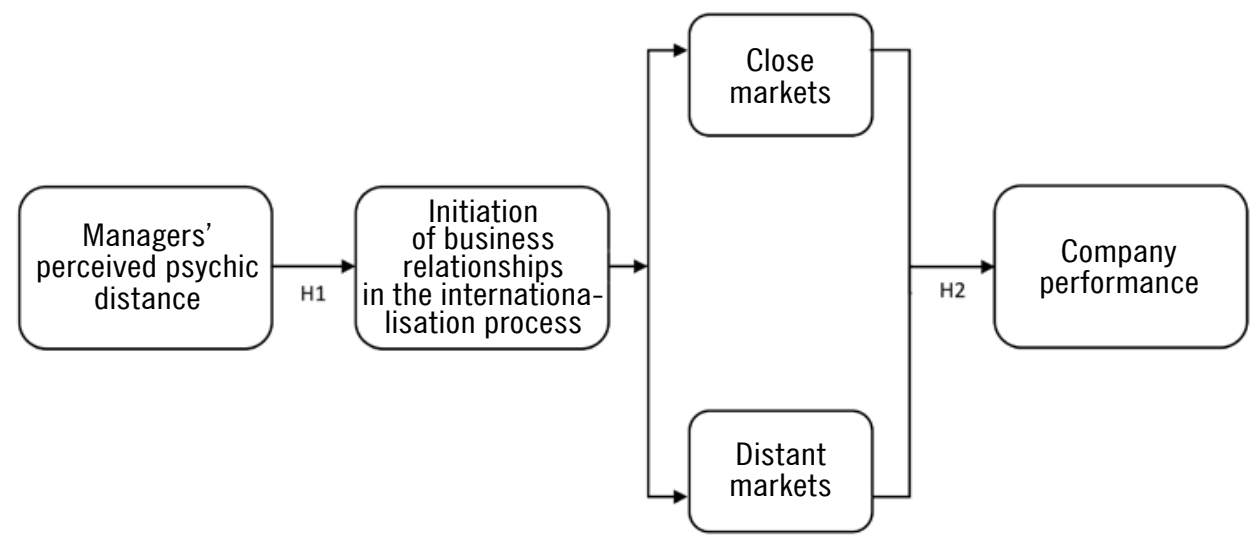

Source: own elaboration.

The empirical data was collected as part of a broader five-year research project on internationalization maturity among firms. The research was conducted thanks to financial support from Poland's National Science Centre, and it was carried out in 2014-2019. The study embraced different aspects of company behavior in the internationalization process, e.g. the formal and informal character or modes of a company's foreign entry. One of these aspects was also psychic distance. 
The article is based on quantitative studies conducted within the abovementioned research project. Prior to deployment, the questionnaire used in the research was discussed with representatives of selected companies. The aim of these exploratory personal interviews connected with psychic distance issues was to:

- determine if our interpretation of psychic distance was clear and understandable to respondents,

- identify (preliminary checking) to what extent psychic distance still matters in the process of initiating business relationships during a foreign market entry, and

- design the final version of the questionnaire for quantitative research.

The interviews were conducted with key informants: presidents and managers of five companies that operate internationally. The informants were selected due to their role as key decision-makers in their companies' internationalizations. The interviews were semi-structured and lasted for one to two hours. Companies were chosen in such a way that they were as diverse as possible in terms of the industry, size, and level of internationalization, including the mode of foreign market entry and number of markets in which the company is active. Questions concentrated on the area of psychic distance, specifically on the knowledge and awareness of the issue, its interpretation by, and its understanding among interviewees. Moreover, the interviewees were asked whether psychic distance influenced the company's decisions in the process of internationalization and whether it impacted the performance of their operations abroad. The interviews were recorded, and transcripts were created to be later analyzed for the purpose of this study.

In this article, we adopt a similar perspective to Nebus and Chai, who propose that "psychic distance be centred on the firm's managers and explain how their cognitive limitations, perceptions, heuristics, and experiences interact with a foreign environment to influence their decision making" (Nebus and Chai, 2014, p. 8). During our discussions with key informants, we learned that they associate psychic distance mainly with cultural distance. Moreover, we found that the definition of psychic distance we were planning to use in the quantitative research was clear for informants: "the distance between the home market and a foreign market resulting from the perception and understanding of cultural and business differences" (Evans et al., 2000, p. 377-378). The key informants indicated that psychic distance still matters in the process of initiation of business relationships during a foreign market entry. They especially underlined the importance of awareness of the differences between the entrant and its (prospective) partners, attention to and preparation for such coopera- 
tion, and above all, assessing one's own abilities in this regard. Moreover, managers generally perceived engagement in psychically distant countries as risky but with the potential to achieve higher profits. These responses and additional expert insights were the basis for the preparation of the final questionnaire we used in the quantitative study.

In the quantitative study, we adopted a single-item measure of psychic distance. Nevertheless, the question was preceded by a proven definition of the concept to ascertain respondents' understanding of the issue. Moreover, many authors consider single-item measures as a useful instrument. This is because in a number of studies, empirical analyses show that single-item measures have a very high predictive validity and that sometimes there is even no difference in this matter between single-item measures and multiple-item measures (e.g. Nagy, 2002; Bergkvist and Rossiter, 2007; Christophersen and Konradt, 2011; Postmes et al., 2013).

The quantitative study was conducted in Poland. The target population consisted of 10,000 companies involved in international business. The sampling frame was a business database purchased from Kompass Poland (a CD-ROM version). The dataset contained companies that represented all sizes, industries, and ownership status from all over Poland. The quantitative study was conducted as a survey based on a structured questionnaire consisting mainly of closed questions. The questionnaire was sent to 1900 companies by post and to 8100 companies by email. Owing to incorrect address information or liquidation of some of the companies in the sample, only 1748 firms received the paper version of the questionnaire. In total, we received 179 responses, resulting in a response rate of $10.2 \%$. An additional 99 responses were received from the online survey. The sample cannot be considered random in particular due to the fact that we were aware of the very high non-response rate to online surveys; nevertheless, convenience samples are also acceptable in the literature (Garson, 2013), and aggregated results represent the subjective perception of foreign markets by respondents.

To ensure data reliability and validity, we analyzed response bias by comparing the first and the last $25 \%$ of answers to the questions concerning: the level of formalization, expansion stages, confidence level, openness to cooperation, sales volume, market share, and profit and return on investment. A comparison of this data revealed that the results were reasonably consistent. The internal consistency of the first and last responses was also confirmed by a $t$-test of independent samples. Furthermore, responses from the paper and the online questionnaire versions were compared. The analysis of standard deviations and means indicated that the results were very simi- 
lar for both groups of data. Furthermore, the results of the $t$-test of independent samples indicated a lack of differences. A total of 278 responses were received. This article is based on answers from 204 questionnaires as the remaining ones had to be excluded owing to missing data. Three of the analyzed questionnaires did not state the number of employees, so analyzes that included company size provided 201 entities.

Most companies in the sample were medium-sized (40.7\%), outnumbering both small $(37.2 \%)$ and large companies (20.6\%). The majority of the companies operated in the manufacturing industry (52.2\%), then services (12.6\%) and wholesale trade (11.5\%). The sample was found to be broadly representative in terms of industry sectors and company size. Most respondents in the study (58.9\%) represented firms with Polish/ foreign capital. A fifth of the companies (20.7\%) were completely foreign-owned, others were private Polish-owned (13.2\%), or state-owned companies (7.2\%).

All variables and categories used in the article are summarised in Table 1.

Table 1. Types of variables and categories used in the analyses

\begin{tabular}{|l|l|}
\hline \multicolumn{1}{|c|}{ Variable } & \multicolumn{1}{c|}{ Description } \\
\hline $\begin{array}{l}\text { Consolidated performance } \\
\text { indicator }\end{array}$ & $\begin{array}{l}\text { This combines four measures of performance - total profits, return } \\
\text { on investment, sales volume, market share - and it is created as } \\
\text { their arithmetic average. }\end{array}$ \\
\hline A-type company & A-type companies usually operate on psychically close markets. \\
\hline B-type company & $\begin{array}{l}\text { B-type companies are active on all markets including psychically } \\
\text { distant ones. }\end{array}$ \\
\hline Small company & Companies that employ 1-49 employees. \\
\hline Medium-sized company & Companies that employ 50-249 employees. \\
\hline Large company & Companies that employ more than 250 employees. \\
\hline Indirect export & Exports through intermediaries. \\
\hline Direct export & Independent export involvement in foreign markets. \\
\hline Licensing & $\begin{array}{l}\text { Entering a foreign market by granting a license to an external entity, } \\
\text { e.g. for a production process or brand. }\end{array}$ \\
\hline $\begin{array}{l}\text { Foreign direct investment } \\
\text { (FDI) }\end{array}$ & $\begin{array}{l}\text { A type of international investment in which a resident of one } \\
\text { economy establishes a significant and lasting influence over a } \\
\text { company in another economy (0ECD iLibrary, 2021). }\end{array}$ \\
\hline
\end{tabular}

Source: own elaboration. 


\section{Results and Discussion}

The starting point for the study was the identification of whether company decisions on the initiation of relationships with foreign actors are determined by managers' perception of psychic distance.

Respondents were asked whether their company preferred relationships with actors located in psychically close markets. They had four options to choose from: "Definitely," "Usually," "No," and "It doesn't matter." Two types of companies - A and B - were created based on the responses received (see Table 2).

A-type companies usually operate on psychically close markets (their managers answered "Definitely" or "Usually"), while B-type companies are active on all markets, including distant ones (their managers answered "No" or "It doesn't matter"), so psychic distance is not an issue for the latter. These two types show the different perceptions of psychic distance among company decision-makers and its role and impact on initiating relationships with actors on the international market.

Table 2. Perceived psychic distance by investigated managers

\begin{tabular}{|c|c|c|}
\hline Type of company & Number of companies & Share of sample \\
\hline A & 133 & $65.2 \%$ \\
\hline B & 71 & $34.8 \%$ \\
\hline Total & 204 & $100 \%$ \\
\hline
\end{tabular}

Source: own elaboration.

The managers of A-type companies preferred to focus on psychically close markets, considering them safer and more suitable for the company's overseas activities. The respondents from B-type companies perceived all international markets as potentially attractive and did not treat psychic distance as an obstacle to foreign operations. The results show that the majority of respondents were inclined to initiate relationships with actors in closer and more familiar environments, meaning that psychic distance affects relationship initiation in new foreign markets, which confirms our first hypothesis (H1).

As mentioned above, scholars previously concentrated mainly on selected modes of foreign market entry, specifically on export or foreign direct investment (FDI). Our 
intention was to look at the issue more broadly and include all forms of company internationalization. The adopted perspective of foreign business relationship initiation enabled us to analyze the two identified types of companies against the background of various modes of foreign market entry (see Table 3).

Table 3. A- and B-type companies versus modes of foreign market entry

\section{Type of company}

A

B
Indirect export

$54.1 \%$

$49.3 \%$
Direct export

$82.7 \%$

$88.7 \%$
Licensing

$3.8 \%$

$4.2 \%$
Foreign direct investment

$9.0 \%$

$19.7 \%$

Source: own elaboration.

As we can see in Table 3, B-type companies more often applied advanced forms of foreign involvement. In contrast to A-type firms, B-type companies were much more interested in FDI and more reluctant to use indirect export. Moreover, B-type companies preferred direct export more often than A-type firms, which requires knowledge and experience for initiating more advanced relationships with foreign actors.

In order to verify the second hypothesis, we analyzed the impact of psychic distance on company performance. Many studies measure performance in absolute performance figures (Hooley et al., 2003). However, absolute measurements of performance such as profit, sales, or market share are difficult to compare between firms of different sizes that operate in different markets and define their markets in different ways. Therefore, based on experiences from earlier research (Fahy et al., 2003; Fonfara et al., 2018), our study measured company performance on a relative basis. We used four performance measurements: two financial ones (profit and ROI) and two market-based ones (sales volume and market share). We investigated company relative performance with a five-point Likert scale, which enabled us to identify if - in the respondents' view - their company's performance is much worse, worse, the same, better, or much better compared to their closest competitors. Following important and valid research recommendations for a broader and more balanced assessment of organizational performance (Eccles, 1991; Kaplan and Norton, 1992), we used the consolidated performance indicator in our study. This combines the four abovementioned measurements of performance and offers their arithmetic average. The consolidated performance indicator was verified by means of reliability analysis, which for the "performance" variable showed a very high Cronbach's alpha value, namely 0.902. Excluding some of the variables from the analysis decreased this figure. Moreover, we conducted 
a correlation analysis, which further demonstrated a strong correlation between all four variables (see Table 4). Furthermore, the consolidated performance indicator proved to be a valuable way for measuring company performance in earlier studies (Fahy et al., 2003; Fonfara et al., 2018).

Table 4. An analysis of the correlation between performance measures: consolidated performance indicator

\begin{tabular}{|l|c|c|c|c|}
\hline Performance measure & Total profits & $\begin{array}{c}\text { Return on } \\
\text { investment (ROI) }\end{array}$ & Sales volume & Market share \\
\hline Total profits & 1.000 & & \\
\hline Return on investment (ROI) & 0.781 & 1.000 & 1.000 & \\
\hline Sales volume & 0.701 & 0.646 & 0.811 & 1.000 \\
\hline Market share & 0.620 & 0.621 & \\
\hline
\end{tabular}

Source: own elaboration.

Table 5. Performance of A- and B-type companies

Type of company

A

B

\section{Consolidated Performance Indicator}

3.28

3.42

Note: Performance scales are average summed score across profit, sales volume, market share, and ROI on a scale: $1=$ much worse than competitors, $2=$ worse than competitors, $3=$ same as competitors, $4=$ better that competitors, $5=$ much better than competitors.

Source: own elaboration.

Table 5 showed that there is a relatively small but visible difference in the performance of both types of companies. The analysis revealed that B-type companies perform relatively better compared to their closest competitors.

Sales are a simple measure of companies' performance and give them direct market feedback. Therefore, sales is the measurement most commonly used by managers, according to a study conducted by Clark (2000). Thus, we decided to check how this element acts in the consolidated performance indicator for the two identified types of companies (see Table 6). Here, again, B-type companies more often showed higher sales compared to their closest competitors. 
Table 6. Level of sales of A- and B-type companies compared to closest competitors

\begin{tabular}{|c|c|}
\hline Type of company & Sales \\
\hline A & 3.36 \\
\hline B & 3.61 \\
\hline
\end{tabular}

Note: Sales as a measure of performance; scale: $1=$ much worse than competitors, $2=$ worse than competitors, $3=$ same as competitors, $4=$ better that competitors, $5=$ much better than competitors.

Source: own elaboration.

The outcomes of our empirical study indicate that a company's attitude to psychic distance influences its performance, which positively supports the second hypothesis (H2).

In order to examine in more detail the studied issue, we analyzed managers' perceived psychic distance, taking into account company size. The results are shown in Table 7.

Table 7. Two types of companies versus their size

\begin{tabular}{|c|c|c|c|c|c|c|}
\hline \multirow{2}{*}{$\begin{array}{c}\text { Type } \\
\text { of company }\end{array}$} & \multicolumn{2}{|c|}{ Small } & \multicolumn{2}{c|}{ Medium-sized } & \multicolumn{2}{c|}{ Large } \\
\hline & $\begin{array}{c}\text { Number } \\
\text { of companies }\end{array}$ & $\begin{array}{c}\text { Share } \\
\text { of sample }\end{array}$ & $\begin{array}{c}\text { Number } \\
\text { of companies }\end{array}$ & $\begin{array}{c}\text { Share } \\
\text { of sample }\end{array}$ & $\begin{array}{c}\text { Number } \\
\text { of companies }\end{array}$ & $\begin{array}{c}\text { Share } \\
\text { of sample }\end{array}$ \\
\hline A & 55 & $72.4 \%$ & 52 & $62.7 \%$ & 24 & $57.1 \%$ \\
\hline B & 21 & $27.6 \%$ & 31 & $37.3 \%$ & 18 & $42.9 \%$ \\
\hline Total: & 76 & $100 \%$ & 83 & $100 \%$ & 42 & $100 \%$ \\
\hline
\end{tabular}

Source: own elaboration.

Table 7 revealed that there were more A-type entities among companies of all sizes. However, managers from smaller companies initiated relationships with psychically close actors relatively more often and represented A-type firms. We saw that the larger the company, the more willing it was to initiate relationships with actors located in more psychically distant markets, behaving as a B-type company. This pattern was particularly evident in the case of large firms. Nevertheless, even among these enterprises, there were more A-type companies.

The performance of A- and B-type companies versus their size is presented in Table 8. 
Table 8. Consolidated performance indicator according to company size and type

\begin{tabular}{|c|c|c|c|}
\hline \multirow{2}{*}{ Type of company } & \multicolumn{3}{|c|}{ Consolidated performance indicator } \\
\hline A & Small company & Medium-sized company & Large company \\
\hline B & 3.07 & 3.40 & 3.44 \\
\hline
\end{tabular}

Note: Performance scales are average summed score across profit, sales volume, market share, and ROI on a scale: $1=$ much worse than competitors, $2=$ worse than competitors, $3=$ same as competitors, $4=$ better that competitors, $5=$ much better than competitors.

Source: own elaboration.

The difference in the performance between A- and B-type companies was especially meaningful if we look at large and small companies. This agrees with other studies. According to the literature, small companies encounter more challenges such as "unknown unknowns" in new markets (Yip et al., 2003). Furthermore, they frequently have limited financial and human resources. On the other hand, large companies - which are often MNEs - have access to a more diversified knowledge and may thus gain new experience. This prior experience has a significant positive impact on the company's performance (Yip et al., 2003). Notably, the most visible difference in performance existed between small A- and B-type companies: namely, if managers from small companies decided to face the challenges of distant foreign markets, they gained the most.

\section{Conclusions}

Based on the empirical study, two types of companies were identified. A-type companies prefer to initiate relationships with actors located in psychically close markets, while B-type companies disregard psychic distance as they often choose psychically distant markets. For A-type companies, psychic distance is a challenge, while for B-type firms it can seem an opportunity (see Table 9). Contrary to Zaheer et al. (2012), our research did not reveal a decreasing influence of psychic distance on managers' decisions regarding internationalization. We confirmed the previous results of Dinner (2019) or Dow and Ferencikova (2010) that psychic distance remains important despite ongoing globalization and continues to impact managers' decisions on foreign market entry (Safari and Chetty, 2019; Puthusserry et al., 2021). 


\section{Table 9. Hypotheses summary}
H1 Confirmed
The psychic distance perceived by Polish managers impacts a company's performance. Companies operating in psychically distant markets (B-type companies) perform relatively better compared to companies initiating relationships with partners in psychically close markets (A-type companies).
The psychic distance perceived by Polish managers impacts a company's
H2 Confirmed performance. Companies operating in psychically distant markets (B-type companies) perform relatively better compared to companies initiating relationships with partners in psychically close markets (A-type companies).

Source: own elaboration.

The literature review on psychic distance indicates potential problems that companies face in the process of internationalization, such as an increase in the level of uncertainty, growth in the number of misunderstandings (Håkanson, 2014; Dow and Baack, and Parente, 2020), or rise in operational costs (Mithani, 2017). However, this challenge linked with psychic distance can be minimized by the international experience of companies, especially when shared among members of senior management (Hutzschenreuter et al., 2015). In the case of high perceived psychic distance, a company may enter a foreign market by establishing a network relationship with local actors (Safari and Chetty, 2019). As existing research confirms, gradual internationalization allows for more knowledge gains from new foreign markets and helps to handle psychic distance and the liability of foreignness (Amal et al., 2013). The initiation of relationships with actors in psychically distant markets may often seem highly complex and risky.

Our research tried to fill the existing research gap on psychic distance in terms of a company's internationalization process by analyzing managers from Poland-based companies. Existing studies concentrate rather on a specific mode of internationalization, mainly exports or a specific foreign market (Kłysik-Uryszek and Kuna-Marszałek, 2014; Olejnik-Nizielska, 2018). Our study analyzed companies that enter different international markets (also very distant ones) by different internationalization modes. This enabled us to obtain a more comprehensive view on the impact of psychic distance on managers from Poland-based companies during the internationalization process. More specifically, contrary to Kłysik-Uryszek and Kuna-Marszałek (2014), we did not confirm that Polish managers prefer a conservative internationalization process, although our study partly agrees with the results of Olejnik-Nizielska (2018), which show that psychic distance does not constitute an important barrier preventing international expansion.

The conducted analysis confirmed previous studies by Ciszewska-Mlinarič, Obłój, and Hülsdau (2019) and Hauke-Lopes (2018), thus supporting the psychic distance 
paradox. Based on our research results, we observed and confirmed the occurrence of the "paradox" that such activities produce better performance than operations in "familiar" locations and areas because less risky markets attract more companies, which increases competition and consequently decreases the level of performance.

Overall, our research shows that managers take psychic distance into account when selecting partners for their operations. This confirms existing studies on psychic distance, which indicate that Polish companies prefer a traditional model of internationalization, and they start foreign expansion from well-known markets with a low perceived psychic distance (Kłysik-Uryszek and Kuna-Marszałek, 2014). Moreover, most of the companies in our study are afraid of engagement in psychically distant countries: most of the studied companies were classified as A-type. This confirms the significance of psychic distance in foreign market choice and allows us to conclude that psychic distance still matters. Based on our study results, we discern that such companies prefer to use less advanced modes of foreign market entry, which as a rule are less risky compared to more advanced ones. Moreover, our study identified links between psychic distance as perceived by managers and company performance. The companies that decided to take up the challenge to operate in psychically distant markets performed better. Our study revealed that company operations in psychically distant markets paid off, especially for small companies.

Our study has some managerial implications. In our opinion, managers should not be afraid to enter psychically distant markets. However, when entering a market with a high psychic distance, we recommend that managers analyze the market thoroughly and define a strategy that includes both real and perceived differences between local and foreign markets. We recommend that managers dedicate their time and effort to develop a business network relationship with foreign business partners that might be helpful in dealing with psychic distance (Hauke-Lopes, 2018). In this respect, what is of great importance is the quality of the business relationship, namely the level of trust, conflict handling, and abilities to deal and communicate with partners from psychically distant markets. By developing business network relationships (Deszczyński, Fonfara, and Dymitrowski, 2017), managers can access different tangible and intangible resources, acquire knowledge on new markets faster, and develop informal relationships helpful in a company's further development. As a result, the company may achieve better results in psychically distant markets.

The presented results have particular limitations. First, the measurements are based on the subjective perceptions of respondents - in the case of both psychic distance and company performance. Second, the research was only conducted among compa- 
nies based in Poland. It could be extended in the future to other countries in the region and the EU. There is a lack of in-depth comparisons among different countries concerning managers' perceptions of psychic distance in the context of its impact on initiating foreign business relationships. Therefore, it is difficult to say whether Poland, for instance, is a typical case for the CEE or the EU. We may only speculate that the long-lasting isolation during the time of communism may still influence managers' perceptions of initiating relationships with foreign partners, especially in distant markets. Third, the choice of less advanced modes of internationalization - even in the case of large companies - is sometimes not a matter of will but a lack of resources. Another limitation of our article is the fact that our study concentrated on the impact of company decisions concerning entering distant markets on their performance. In practice, a reverse influence may also exist, thus initiating international business relationships may be determined by company performance and the available resources mentioned earlier.

A possible avenue for further research would be to focus on the impact of psychic distance depending on the industry and the international experience of the managers involved. Furthermore, because of the specificity and restrictions of anonymous quantitative studies, we could not scrutinize evaluate psychic distance from both sides of the relationship, i.e. that of the seller's and that of the buyer's. An introduction to such an interactive analysis (Håkansson and Snehota, 2017) would probably allow for the identification of the extent to which two actors are ready to invest in their relationship, both in low and high psychic distance situations.

\section{References}

Amal, M., Baffour Awuah, G., Raboch, H., and Anderson, S. (2013). Differences and Similarities of the Internationalization Processes of Multinational Companies from Developed and Emerging Countries. European Business Review, 25(5), 955-534. https://doi.org/10.1108/EBR-08-2012-0048.

Ambos, B., and Håkanson, L. (2014). The Concept of Distance in International Management Research. Journal of International Management, 20(1), 1-7. https://doi.org/10.1016/j.intman.2013.10.003.

Ambos, B., Leicht-Deobald, U. and Leinemann, A. (2019). Understanding the Formation of Psychic Distance Perceptions: Are Country-Level or Individual-Level Factors More Important?, International Business Review, 28(4), 660-671. https://doi.org/10.1016/j.ibusrev.2019.01.003.

Azar, G., and Drogendijk, R. (2014). Psychic Distance, Innovation, and Firm Performance. Management International Review, 54(5), 581-613. https://doi.org/10.1007/s11575-014-0219-2.

Azar, G., and Drogendijk, R. (2016). Cultural Distance, Innovation and Export Performance: An Examination of Perceived and Objective Cultural Distance. European Business Review, 28(2), 176-207. https://doi.org/10.1108/EBR-06-2015-0065.

Bergkvist, L., and Rossiter, J.R. (2007). The Predictive Validity of Multiple-Item versus Single-Item Measures of the Same Constructs. Journal of Marketing Research, 44(2), 175-84.

https://doi.org/10.1509/jmkr.44.2.175. 
Bodlaj, M., and Vida, I. (2018). Factors Underlying Cultural and Psychic Distance in Cross-National Activities of Export Managers: Qualitative Insights from a CEE Country. Journal of East European Management Studies, 23(3), 351-76. https://doi.org/10.5771/0949-6181-2018-3-351.

Brewer, P.A. (2007). Operationalizing Psychic Distance: A Revised Approach. Journal of International Marketing, 15(1), 44-66. https://doi.org/10.1509/jimk.15.1.044.

Chapman, M., Gajewska-De Mattos, H., Clegg, J. and Buckley, P.J. (2008). Close Neighbours and Distant Friends-Perceptions of Cultural Distance. International Business Review, 17, 217-34. https://doi.org/10.1016/j.ibusrev.2008.01.007.

Christophersen, T., and Konradt, U. (2011). Reliability, Validity, and Sensitivity of a Single-Item Measure of Online Store Usability. International Journal of Human Computer Studies, 69(4), 269-80. https://doi.org/10.1016/j.ijhcs.2010.10.005.

Ciszewska-Mlinarič, M., Obłój, K., and Hülsdau, M. (2019). Post-Entry Strategic Significance of Export Market: How Does Psychic Distance Work? The Evidence from European SMEs. Journal of East European Management Studies, 24(2), 235-258.

https://doi.org/10.5771/0949-6181-2019-2-235.

Ciszewska-Mlinarič, M., and Trąpczyński, P. (2016). The Psychic Distance Concept: A Review of 25 Years of Research (1990-2015). Journal of Management and Business Administration. Central Europe, 24(2), 2-31. https://doi.org/10.7206/jmba.ce.2450-7814.167.

Ciszewska-Mlinarič, M., Wójcik, P., and Obłój, K. (2020). Learning Dynamics of Rapidly Internationalizing Venture: Beyond the Early Stage of International Growth in a CEE Context. Journal of Business Research, 108(January), 450-465. https://doi.org/10.1016/j.jbusres.2019.03.002.

Clark, B.H. (2000). Managerial Perceptions of Marketing Performance: Efficiency, Adaptability, Effectiveness and Satisfaction. Journal of Strategic Marketing, 8(1), 3-25.

https://doi.org/10.1080/096525400346286.

Datta, Deepak K., and Puia, G. (1995). Cross-Border Acquisitions: An Examination of the Influence of Relatedness and Cultural Fit on Shareholder Value Creation in U. S. Acquiring Firms. Management International Review, 35(4), 337-59. https://doi.org/10.2307/40228285.

Deszczyński, B., Fonfara, K., and Dymitrowski, A. (2017). The Role of Relationships in Initiating the Internationalisation Process in B2B Markets. Entrepreneurial Business and Economics Review, 5(4), 91-109. https://doi.org/10.15678/EBER.2017.050404.

Dikova, D. (2009). Performance of Foreign Subsidiaries: Does Psychic Distance Matter? International Business Review, 18(1), 38-49. https://doi.org/10.1016/j.ibusrev.2008.11.001.

Dinner, I.M., Kushwaha, T., and Benedict, J.-B., Steenkamp, E.M.M. (2019). Psychic Distance and Performance of MNCs during Marketing Crises. Journal of International Business Studies, 50(3), 339-364. https://doi.org/10.1057/s41267-018-0187-z.

Dow, D., Baack, D., and Parente, R. (2020). The Role of Psychic Distance in Entry Mode Decisions: Magnifying the Threat of Opportunism or Increasing the Need for Local Knowledge? Global Strategy Journal, 10(2), 309-34. https://doi.org/10.1002/gsj.1309.

Dow, D., and Ferencikova, S. (2010). More than Just National Cultural Distance: Testing New Distance Scales on FDI in Slovakia. International Business Review, 19(1), 46-58. https://doi.org/10.1016/j.ibusrev.2009.11.001.

Drogendijk, R., and Slangen, A. (2006). Hofstede, Schwartz, or Managerial Perceptions? The Effects of Different Cultural Distance Measures on Establishment Mode Choices by Multinational Enterprises. International Business Review, 15(4), 361-80.

https://doi.org/10.1016/j.ibusrev.2006.05.003.

Eccles, R. (1991). The Performance Measurement Manifesto. Harvard Business Review, 69(1), 131-37. https://hbr.org/1991/01/the-performance-measurement-manifesto. 
Ellis, P.D. (2008). Does Psychic Distance Moderate the Market Size-Entry Sequence Relationship? Journal of International Business Studies, 39(3), 351-69.

https://doi.org/10.1057/palgrave.jibs.8400360.

Evans, J., and Mavondo, F.T. (2002). Psychic Distance and Organisational Performance: An Empirical Examination of International Retailing Operations. Journal of International Business Studies, 33(3), 515-532. https://doi.org/10.1057/palgrave.jibs.8491029.

Evans, J., Treadgold, A., and Mavondo, F.T. (2000). Psychic Distance and the Performance of International Retailers - A Suggested Theoretical Framework. International Marketing Review, 17(4/5), 373-391. https://doi.org/10.1108/02651330010339905.

Fahy, J., Hooley, G., Beracs, J., Fonfara, K. and Gabrijan, V. (2003). Privatisation and Sustainable Competitive Advantage in the Emerging Economies of Central Europe. Management International Review, 43(4), 407. https://doi.org/10.2307/40835942.

Fonfara, K. (2009). Zachowanie przedsiębiorstwa w procesie internacjonalizacji: podejście sieciowe. Warszawa: PWE.

Fonfara, K., Ratajczak-Mrozek, M., and Małys, Ł. (eds.) (2018). The Internationalisation Maturity of the Firm. Cambridge Scholars Publishing.

Garson, D. (2013). Survey Research \& Sampling (Statistical Associates “Blue Book” Series Book 7). Asheboro, NC: Statistical Associate Publishing.

Håkanson, L. (2014). The Role of Psychic Distance in International Trade: A Longitudinal Analysis. International Marketing Review, 31, 210-36. https://doi.org/10.1108/IMR-04-2013-0079.

Håkanson, L., and Ambos, B. (2010). The Antecedents of Psychic Distance. Journal of International Management, 16(3), 195-210. https://doi.org/10.1016/j.intman.2010.06.001.

Håkansson, H., and Snehota, I. (eds.) (2017). No Business Is an Island: Making Sense of the Interactive Business World. Emerald Publishing Limited. https://doi.org/10.1108/9781787145498.

Hauke-Lopes, A. (2018). Znaczenie dystansu psychicznego w rozwoju relacji biznesowych na rynku zagranicznym. Przedsiębiorczość i Zarzq̨dzanie, XIX(2), 209-217.

Hooley, G., Fahy, J., Greenley, G., Beracs, J., Fonfara, K., and Snoj, B. (2003). Market Orientation in the Service Sector of the Transition Economies of Central Europe. European Journal of Marketing, 37(1/2), 86-106. https://doi.org/10.1108/03090560310453975.

Hutzschenreuter, Th., Kleindienst, I., and Lange, S. (2014). Added Psychic Distance Stimuli and MNE Performance Effects of Added Cultural, Governance, Geographic, and Economic Distance in MNEs' International Expansion. Journal of International Management, 20, 38-54. https://doi.org/10.1016/j.intman.2013.02.003.

Hutzschenreuter, Th., Kleindienst, I., and Lange, S. (2015). The Concept of Distance in International Business Research: A Review and Research Agenda. International Journal of Management Reviews, 1-20. https://doi.org/10.1111/ijmr.12065.

Johanson, J., and Vahlne, J.E. (2009). The Uppsala Internationalization Process Model Revisited: From Liability of Foreignness to Liability of Outsidership. Journal of International Business Studies, 40(9), 1411-1431. https://doi.org/10.1057/jibs.2009.24.

Johanson, J., and Wiedersheim, P. (1975). The Internationalization Process of the Firm - Four Swedish Case Studies. Journal of Management Studies, 12(3), 305-23.

https://doi.org/10.1111/j.1467-6486.1975.tb00514.x.

Kaplan, R., and Norton, D. (1992). The Balanced Scorecard - Measures That Drive Performance. Harvard Business Review, 70(1), 71-79. https://hbr.org/1992/01/the-balanced-scorecard-measuresthat-drive-performance-2.

Kłysik-Uryszek, A., and Kuna-Marszałek, A. (2014). Psychic and Geographic Distance in the Process of Firm Internationalization. Example of Companies from Poland and Lodz Region. Business and Economic Horizons, 10(1), 1-9. https://doi.org/10.15208/beh.2014.01. 
Kontinen, T., and Ojala, A. (2010). Internationalization Pathways of Family SMEs: Psychic Distance as a Focal Point. Journal of Small Business and Enterprise Development, 17(3), 437-54. https://doi.org/10.1108/14626001011068725.

Liu, S.Y.H., Deligonul, S., Tamer Cavusgil, S., and Shen Chiou, J. (2021). Addressing Psychic Distance and Learning in International Buyer-Seller Relationships: The Role of Firm Exploration and Asset Specificity. Journal of World Business, 56(4), 1090-9516.

https://doi.org/10.1016/j.jwb.2021.101208.

Luo, Yadong, Oded, Mee-Kau Shenkar, and Nyaw (2001). A Dual Parent Perspective on Control and Performance in International. Journal of International Business Studies, 32.

Magnani, G., Zucchella, A., Eliete Floriani, D., and Floriani, E. (2018). The Logic behind Foreign Market Selection: Objective Distance Dimensions vs. Strategic Objectives and Psychic Distance. International Business Review, 27(1), 1-20. https://doi.org/10.1016/j.ibusrev.2017.10.009.

Maseland, R., Dow, D., and Steel, P. (2018). The Kogut and Singh National Cultural Distance Index: Time to Start Using It as a Springboard Rather than a Crutch. Journal of International Business Studies, 49, 1154-66. https://doi.org/10.1057/s41267-018-0183-3.

Mithani, Murad A. (2017). Liability of Foreignness, Natural Disasters, and Corporate Philanthropy. Journal of International Business Studies, 48, 941-963. https://doi.org/10.1057/s41267-017-0104-x.

Moalla, E., and Mayrhofer, U. (2020). How Does Distance Affect Market Entry Mode Choice? Evidence from French Companies. European Management Journal, 38(1), 135-145. https://doi.org/10.1016/j.emj.2019.08.002.

Musso, F., and Francioni, B. (2012). How Do Smaller Firms Select Foreign Markets ? International Journal of Marketing Studies, 4(6), 44-53. https://doi.org/10.5539/ijms.v4n6p44.

Nagy, M.S. (2002). Using a Single-Item Approach to Measure Facet Job Satisfaction. Journal of Occupational and Organizational Psychology, 75(1), 77-86. https:/doi.org/10.1348/096317902167658.

Navarro-García, A., Peris-Oritz, M. and Barrera-Barrera, R. (2016). Market Intelligence Effect on Perceived Psychic Distance, Strategic Behaviours and Export Performance in Industrial SMEs. Journal of Business and Industrial Marketing, 31(3), 365-80. https://doi.org/10.1108/JBIM-03-2013-0065.

Nebus, J., and Kah Hin Chai (2014). Putting the 'Psychic' Back in Psychic Distance: Awareness, Perceptions, and Understanding as Dimensions of Psychic Distance. Journal of International Management, 20(1), 8-24. https://doi.org/doi.org/10.1016/j.intman.

Nizielska, A. (2013). The Role of Psychic Distance in the Process of Companies Internationalization - Review of Research Results. Journal of Economics \& Management, 13, 85-99.

Nordman, E.R., and Tolstoy, D. (2014). Does Relationship Psychic Distance Matter for the Learning Processes of Internationalizing SMEs? International Business Review, 23(1), 30-37. https://doi.org/10.1016/j.ibusrev.2013.08.010.

O'Grady, Shawna, and Lane, H.W. (1996). The Psychic Distance Paradox. Journal of International Business Studies, 27(2), 309-333. https://doi.org/10.2307/155287.

OECD-ilibrary (2021). Foreign direct investment (FDI). Obtained from: https://www.oecd-ilibrary. org/finance-and-investment/foreign-direct-investment-fdi/indicator-group/english_9a523b18-en https://doi.org/10.1787/9a523b18-en.

Ojala, A. (2015). Geographic, Cultural, and Psychic Distance to Foreign Markets in the Context of Small and New Ventures. International Business Review, 24(5), 825-835. https://doi.org/10.1016/j.ibusrev.2015.02.007.

Olejnik-Nizielska, A. (2018). Managers' Perceptions about the Importance of Psychic Distance in the Process of Companies' Internationalization - Company G Case. Przedsiębiorczosć i Zarzqdzanie, XIX(2), 231-239. 
Paul, J., and Criado, A.R. (2020). The Art of Writing Literature Review: What Do We Know and What Do We Need to Know? International Business Review, 29(4), 101717.

https://doi.org/10.1016/j.ibusrev.2020.101717.

Pla-Barber, J. (2001). The Internalisation of Foreign Distribution and Production Activities New Empirical Evidence from Spain. International Business Review, 10. www.elsevier.com/locate/ibusrev.

Postmes, T., Haslam, T.A., and Jans, L. (2013). A Single-Item Measure of Social Identification: Reliability, Validity, and Utility. British Journal of Social Psychology, 52(4), 597-617. https://doi.org/10.1111/bjso.12006.

Puthusserry, P., Khan, Z., Nair, S.R., and King, T. (2021). Mitigating Psychic Distance and Enhancing Internationalization of Fintech SMEs from Emerging Markets: The Role of Board of Directors. British Journal of Management. https://doi.org/10.1111/1467-8551.12502.

Safari, A., and Chetty, S. (2019). Multilevel Psychic Distance and Its Impact on SME Internationalization. International Business Review, 28(4), 754-65. https://doi.org/10.1016/j.ibusrev.2019.03.001.

Santos, J.C., Barandas-Karl, H., and Martins, F.V. (2017). The Psychic Distance Hazards in Cross-Border Acquisition Performance: An Empirical Study of Cross-Border Acquisitions from 26 Countries. Distance in International Business: Concept, Cost and Value, 183-206. https://doi.org/doi:10.1108/S1745-886220170000012010.

Sousa, C.M.P., and Bradley, F. (2006). Cultural Distance and Psychic Distance: Two Peas in a Pod? Journal of International Marketing, 14(1), 49-70. https://doi.org/10.1509/jimk.14.1.49.

Trade Map (2019). Trade Statistics for International Business Development. https://www.trademap.org/Index.aspx.

Tung, R.L., and Stahl, G.K. (2018). The Tortuous Evolution of the Role of Culture in IB Research: What We Know, What We Don't Know, and Where We Are Headed. Journal of International Business Studies, 49, 1167-89. https://doi.org/10.1057/s41267-018-0184-2.

Tuzová, M., Toulová, M., Straka, J. and Kubíčková, L. (2015). Can Uppsala Model Explain the Internationalisation of Central European SMEs? European Journal of Business Science and Technology, 1(2), 149-64. www.ejobsat.com.

Vahlne, J.-E., and Johanson, J. (2017). From Internationalization to Evolution: The Uppsala Model at 40 Years. Journal of International Business Studies, 48, 1087-1102. https://doi.org/10.1057/s41267-017-0107-7.

Verbeke, A., and Wenlong, Y. (2016). The Impact of 'Distance' on Multinational Enterprise Subsidiary Capabilities: A Value Chain Perspective. Multinational Business Review, 24(2), 168-90. https://doi.org/10.1108/MBR-05-2015-0021.

Wach, K. (2015). Entrepreneurship without Borders: Do Borders Matter for International Entrepreneurship? Problemy Zarzadzania, 1(51), 82-92. https://doi.org/10.7172/1644-9584.51.6.

Yip, G.S., Biscarri, J.G., and Monti, J.A. (2003). The Role of the Internationalization Process in the Performance of Newly Internationalizing Firms. Journal of International Marketing 8(3), 10-35. https://doi.org/10.1509/jimk.8.3.10.19635.

Zaheer, S., Schomaker, M.S., and Nachum, L. (2012). Distance without Direction: Restoring Credibility to a Much-Loved Construct. Journal of International Business Studies, 43(1), 18-27. https://doi.org/10.1057/jibs.2011.43. 